\title{
Low-Intensity Ultrasound Decreases Ischemia-Induced Edema by Inhibiting $N$-Methyl-D-Aspartic Acid Receptors
}

\author{
Binika Hada, Mrigendra Bir Karmacharya, Byung Hyune Choi, and So Ra Park
}

\begin{abstract}
Background: We have previously shown that low-intensity ultrasound (LIUS), a noninvasive mechanical stimulus, inhibits brain edema formation induced by oxygen and glucose deprivation (OGD) or treatment with glutamate, a mediator of OGD-induced edema, in acute rat hippocampal slice model in vitro. Methods: In this study, we treated the rat hippocampal slices with $N$-methyl-D-aspartic acid (NMDA) or (S)-3,5-dihydroxyphenylglycine (DHPG) to determine whether these different glutamate receptor agonists induce edema. The hippocampal slices were then either sonicated with LIUS or treated with $N$-methyl-D-aspartic acid receptor (NMDAR) antagonists, namely, MK-801 and ketamine, and observed their effects on edema formation. Results: We observed that treatment with NMDA, an agonist of ionotropic glutamate receptors, induced brain edema at similar degrees compared with that induced by OGD. However, treatment with DHPG, an agonist of metabotropic glutamate receptors, did not significantly induce brain edema. Treatment with the NMDAR antagonists MK-801 or ketamine efficiently prevented brain edema formation by both OGD and NMDA in a concentration-dependent manner. $N$-Methyl-D-aspartic acid-induced brain edema was alleviated by LIUS in an intensity-dependent manner when ultrasound was administered at 30,50 , or $100 \mathrm{~mW} / \mathrm{cm}^{2}$ for 20 minutes before the induction of the edema. Furthermore, LIUS reduced OGD- and NMDA-induced phosphorylation of NMDARs at Y1325. Conclusion: These results suggest that LIUS can inhibit OGD- or NMDA-induced NMDAR activation by preventing NMDAR phosphorylation, thereby reducing a subsequent brain edema formation. The mechanisms by which LIUS inhibits NMDAR phosphorylation need further investigation.
\end{abstract}

RÉSUMÉ: Des ultrasons de faible intensité peuvent réduire des oedèmes cérébraux consécutifs à un AVC ischémique en inhibant l'action des récepteurs NMDA. Contexte: Comme nous l'avons montré précédemment dans le cas d'un modèle in vitro utilisant des coupes d'hippocampes de rats, des ultrasons de faible intensité, des stimuli mécaniques non-invasifs, peuvent inhiber la formation d'œdèmes au cerveau induits par la privation en apports d'oxygène et de glucose ou par un traitement au glutamate, ce dernier étant un médiateur des œdèmes induits par une telle privation. Méthodes: Dans la présente étude, nous avons soumis ces coupes à un traitement d'acide-N-méthyl-D-aspartique (NMDA) ou de (S)-3,5-dihydroxyphénylglycine (DHPG) afin de vérifier dans quelle mesure ces agonistes des récepteurs du glutamate pouvaient provoquer un œdème cérébral. À cet effet, nos coupes d'hippocampes de rats ont été soit soumises à des ultrasons de faible intensité ou ont fait l'objet d'un traitement avec des antagonistes affectant les récepteurs NMDA, à savoir le MK-801 et la kétamine. Nous avons ensuite évalué leurs effets respectifs en ce qui regarde la formation d'œdèmes. Résultats: Nous avons constaté qu'un traitement au NMDA, un agoniste des récepteurs ionotropiques du glutamate, provoquait, si on le compare à la privation en apports d'oxygène et de glucose, un œdème cérébral de sévérité comparable. Cela dit, un traitement mené avec le (S)-3,5-DHPG, un agoniste des récepteurs métabotropes du glutamate, n'a pas entraîné de façon significative des œdèmes cérébraux. En fonction de l'utilisation concentrations précises, des traitements au moyen du MK-801 ou de la kétamine ont par ailleurs prévenu de façon efficace l'apparition d'œdèmes cérébraux, peu importe si ces derniers étaient attribuables à une privation en apports d'oxygène et de glucose ou au NMDA. Les odèmes cérébraux produits par le NMDA ont aussi été atténués pendant 20 minutes par des ultrasons à des niveaux spécifiques de faible intensité, soit 30, 50 ou $100 \mathrm{~mW} / \mathrm{cm}^{2}$. Qui plus est, ces ultrasons ont permis de réduire la phosphorylation des récepteurs NMDA à Y1325. Conclusions: Ces résultats donnent à penser que des ultrasons de faible intensité peuvent inhiber l'activation des récepteurs NMDA produite par le NMDA et la privation en apports d'oxygène et de glucose en empêchant la phosphorylation des récepteurs NMDA, réduisant ainsi la formation d'autres œè̀mes cérébraux. Mieux comprendre les mécanismes en vertu desquels les ultrasons de faible intensité inhibent la phosphorylation des récepteurs NMDA nécessitera néanmoins de plus amples travaux de recherche.

Keywords: Low-intensity ultrasound, Brain edema, Ischemia, Oxygen and glucose deprivation, $N$-Methyl-D-aspartate receptor doi:10.1017/cjn.2018.331 Can J Neurol Sci. 2018; 45: 675-681

\section{INTRODUCTION}

Cytotoxic brain edema, a predominant event following traumatic brain injury and cerebral infarct, is one of the major mortality factors. It is caused by a sustained intracellular accumulation of water in the brain. ${ }^{1}$ Glutamate, one of the principal neurotransmitters, has
From the Department of Biomedical Sciences, Inha University College of Medicine, Incheon, Korea (BH, BHC); Department of Physiology and Biophysics, Inha University College of Medicine, Incheon, Korea (MBK, SRP)

Received May 14, 2018. Final Revisions Submitted June 19, 2018. Date of ACCEPTANCE June 27, 2018.

Correspondence to: So Ra Park, Department of Physiology and Biophysics, Inha University College of Medicine, Incheon 400-103, Korea. Email: srpark@inha.ac.kr 
been shown to be associated with cytotoxic brain edema. Under normal physiological conditions, glutamate is released into nerve terminal synapses at millimolar concentrations and facilitates excitatory synaptic transmission. However, under ischemic conditions, extracellular glutamate levels increase by more than 150 fold within 30 minutes of the ischemic insult. This extraordinarily high level of glutamate triggers a massive influx of ions and water into cells, resulting in their extensive swelling. ${ }^{2}$

Activation of pre-synaptic and post-synaptic glutamate receptors (GluRs) after substantial glutamate release has been implicated in cytotoxic edema formation following ischemia. An ischemic injury, for example, under conditions of oxygen and glucose deprivation (OGD), causes a major energy failure and leads to a massive release of glutamate, which results in an excessive activation of GluRs. The activation of both ionotropic and metabotropic GluRs (iGluR and mGluR, respectively) stimulates an ion influx through isoform 1 of $\mathrm{Na}^{+}-\mathrm{K}^{+}-\mathrm{Cl}^{-}$cotransporters (NKCC1). ${ }^{3,4}$ Activation of iGluRs, in particular that of the $N$-methyl-D-aspartate receptors (NMDARs), causes a marked water influx via water channel proteins. This is accompanied by an excessive cation influx (mainly $\mathrm{Na}^{+}, \mathrm{K}^{+}$, and $\mathrm{Ca}^{2+}$ ) followed by anions (mainly $\mathrm{Cl}^{-}$), all contributing to the ensuing cytotoxic edema formation. ${ }^{5}$

We have been studying the effects of low-intensity ultrasound (LIUS), a special type of noninvasive mechanical stimulation, to explore its latent therapeutic potentials in several disease models. In previous studies, we have demonstrated the cytoprotective, anti-inflammatory, and anti-oxidative effects of LIUS stimulation in various cell types and disease models including brain edema, ${ }^{6}$ Parkinson's disease, ${ }^{7}$ eye disease, ${ }^{8,9}$ arthritis, ${ }^{10}$ and others. ${ }^{11}$ In particular, we have shown that LIUS stimulation inhibits brain edema formation in rat brains by altering the localization of the water channel protein aquaporin-4 (AQP4) in astrocytic foot processes. ${ }^{6}$ However, the mechanism of the OGD-induced edema in our model and the upstream mechanism of the LIUS action leading to the modulation of AQP4 functions remain largely unsolved.

In this study, we investigated further into the mechanisms of LIUS-induced inhibition of edema formation in an in vitro model of ischemia in acutely prepared rat hippocampal slices. It would be relevant here to note that hippocampal slice culture model has long been used as a well-known and well-established model for the study of various brain diseases, ${ }^{12,13}$ including ischemic brain edema, ${ }^{14}$ owing to its important clinical and pre-clinical therapeutic applications. As the activation of NMDARs has been implicated in cytotoxic edema by activating AQP4 functions via phosphorylation, ${ }^{15}$ we thought primarily that NMDARs, whose activation precedes that of AQP4 and NKCC1 in signal hierarchy of the cytotoxic edema formation, could be the upstream targets of LIUS. Furthermore, because NMDAR subunits have been reported to be highly sensitive to mechanical stimulation, ${ }^{16}$ we assumed that LIUS could modulate NMDAR functions directly. In this study, we first establish that exposure of rat hippocampal slices to either ischemic conditions or the iGluR agonist NMDA induces edema. In addition, we explore the action of ultrasound stimulation on the NMDA-induced edema formation and discuss a possible mechanism by which ultrasound treatment resolves the edema. We demonstrate that ultrasound stimulation changes the levels of tyrosine-phosphorylated NR2A subunit of NMDARs, which might help prevent edema progression.

\section{MATERIALS AND METHODS}

\section{Animals}

All animals used in this study were treated in accordance with the ethical procedures outlined by the INHA UniversityInstitutional Animal Care and Use Committee.

\section{Chemicals and Antibodies}

$\mathrm{N}$-Methyl-D-aspartic acid was purchased from Sigma-Aldrich (St Louis, MO, USA). The selective group I mGluR agonist $(S)$ 3,5-dihydroxyphenylglycine (DHPG) was purchased from Tocris Bioscience (Abingdon, UK). The rabbit polyclonal antiNMDAR2A (phospho Y1325) antibody was purchased from Abcam (Cambridge, MA, USA). The mouse monoclonal anti- $\beta$ actin antibody and the horseradish peroxidase-conjugated anti-rat or anti-mouse secondary antibodies were purchased from Santa Cruz Biotechnology (Dallas, TX, USA). For intraperitoneal anesthesia, tiletamine-zolazepam was purchased from Virbac Laboratories (Carros, France) and xylazine from Bayer (Gyeonggi-do, Korea).

\section{Preparation of Hippocampal Slices and Induction of Edema In Vitro}

Hippocampal slices were prepared as described in our previous publication. ${ }^{6}$ Briefly, male Sprague-Dawley rats (body weight $=$ 280-300 g) were anesthetized with $50 \mathrm{mg} / \mathrm{kg}$ tiletamine-zolazepam and $10 \mathrm{mg} / \mathrm{kg}$ xylazine intraperitoneally. The anesthetized rats were decapitated, and the cranium was opened. The brain was rapidly removed and immediately immersed in iced normoxic artificial CSF (ACSF) solution composed of $124 \mathrm{mM} \mathrm{NaCl}, 3 \mathrm{mM}$ $\mathrm{KCl}, 10 \mathrm{mM}$ glucose, $26 \mathrm{mM} \mathrm{NaHCO}_{3}, 1.25 \mathrm{mM} \mathrm{NaH}_{2} \mathrm{PO}_{4}, 2 \mathrm{mM}$ $\mathrm{CaCl}_{2}$, and $1 \mathrm{mM} \mathrm{MgCl}_{2}$, exhibiting an osmolarity of $305-$ $315 \mathrm{mOsmol}$. To achieve normoxia, the ACSF was equilibrated with $95 \% \mathrm{O}_{2} / 5 \% \mathrm{CO}_{2}$. The brain was cut longitudinally to separate the two hemispheres, and the hippocampi were scooped out from both hemispheres. The hippocampi were immediately added into iced ACSF solution. Each hippocampus was mounted on the stage of a tissue chopper (McIlwain Tissue Chopper; Mickle Laboratory Engineering, Surrey, UK), and slices of $400-\mu \mathrm{m}$ thickness were prepared from both hippocampi. After cutting, all slices were separated and maintained in ACSF solution for 2 hours at room temperature $\left(20-25^{\circ} \mathrm{C}\right)$ before further experimentation (Figure 1A).

Ischemic edema was induced in these acutely prepared hippocampal slices by incubating them for 1 hour in an oxygen- and glucose-deprived ACSF solution. This OGD solution consisted of $124 \mathrm{mM} \mathrm{NaCl}, 3 \mathrm{mM} \mathrm{KCl}, 10 \mathrm{mM}$ mannitol, $26 \mathrm{mM} \mathrm{NaHCO}_{3}$, $1.25 \mathrm{mM} \mathrm{NaH} \mathrm{PO}_{4}, 2 \mathrm{mM} \mathrm{CaCl}$, and $1 \mathrm{mM} \mathrm{MgCl}_{2}$ with an osmolarity of 305-315 mOsmol and was equilibrated with $95 \%$ $\mathrm{N}_{2} / 5 \% \mathrm{CO}_{2}$.

\section{Ultrasound Stimulation}

Hippocampal slices were stimulated with LIUS, as described in our previous publication. ${ }^{6}$ Briefly, a self-manufactured ultrasound generator that produces ultrasonic waves of $1 \mathrm{MHz}$ frequency was set to continuous mode. The intensity and the treatment time can be controlled in this apparatus (Figure 1B). The hippocampal slices in their cell culture dishes were placed on ultrasound transducers and stimulated by ultrasound with acoustic intensities of 30,50 , or $100 \mathrm{~mW} / \mathrm{cm}^{2}$ for 20 minutes before further 


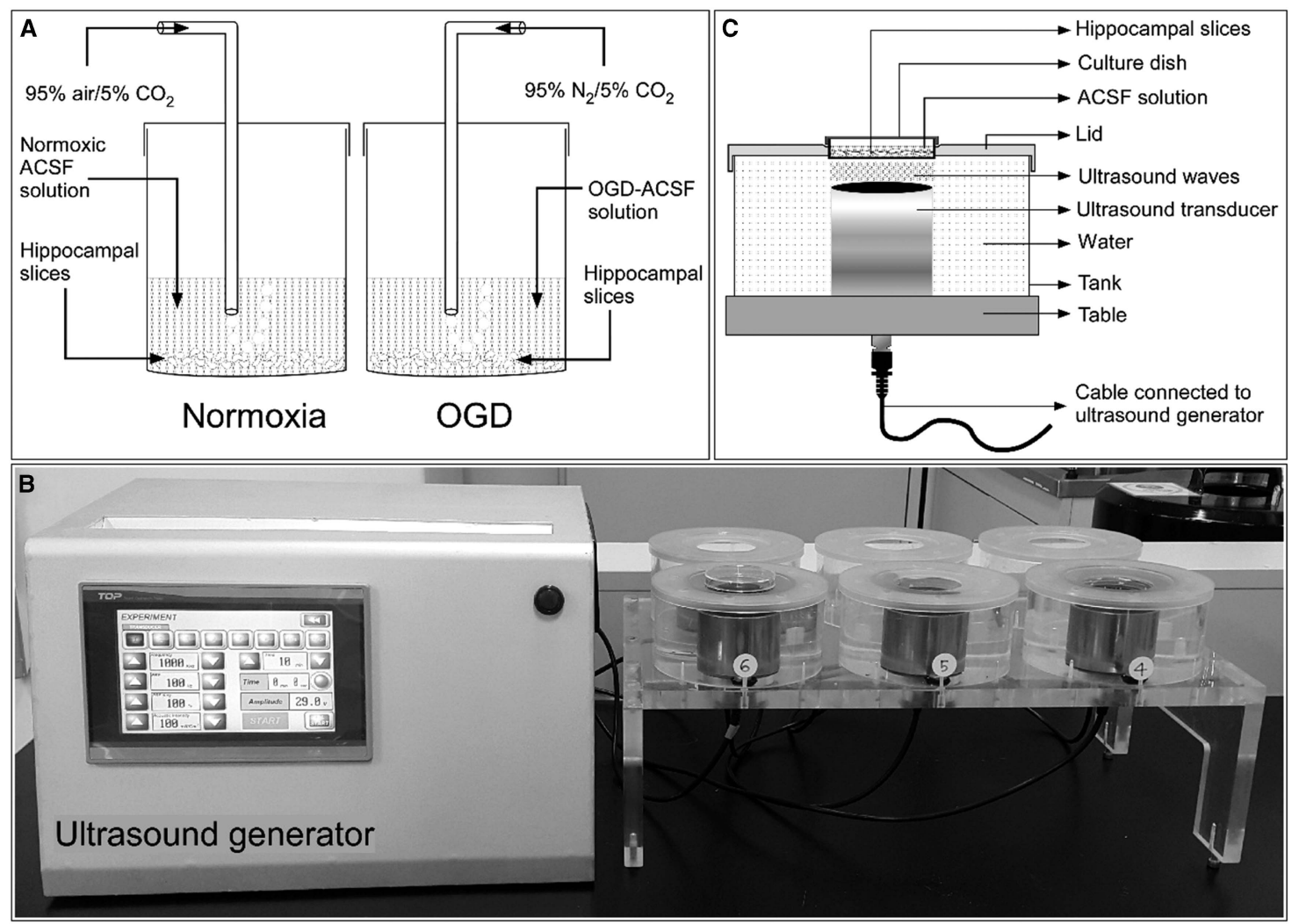

Figure 1: General experimental setup. (A) Schematic showing incubation of rat hippocampal slices in normoxic and oxygen and glucose deprivation (OGD) conditions. (B) A self-manufactured ultrasound generator connected to the ultrasound exposure system. $(C)$ Schematic diagram with proportional dimensions representing the geometry and positioning of the ultrasound exposure system. ACSF = artificial CSF.

drug or OGD treatment (Figure 1C). All experiments included a control group consisting of hippocampal slices incubated in normoxic ACSF solution without any chemical treatment or ultrasound stimulation.

\section{Water Content Analysis}

The edema formation in hippocampal slices was evaluated by determining the water content in percent for each slice. The method used has been published previously. ${ }^{6}$ Briefly, immediately following incubation, hippocampal slices were weighed on a microbalance on pre-weighed aluminum foils, and the weights measured were considered as the "wet weight." After a 24-hour period of desiccation at $80^{\circ} \mathrm{C}$, the slices were weighed again and recorded as the "dry weight." The water content was calculated using the following formula:

$$
\text { water content }=\frac{(\text { wet weight }- \text { dry weight })}{\text { wet weight }} \times 100 \%
$$

\section{Western Blotting Analysis}

The hippocampal slices were homogenized in radioimmunoprecipitation assay (RIPA) buffer with the composition of $0.5 \%$ Nonidet P-40, $20 \mathrm{mM}$ Tris-Cl (pH 8.0), $50 \mathrm{mM} \mathrm{NaCl}$, $50 \mathrm{mM} \mathrm{NaF}, 100 \mu \mathrm{M} \mathrm{Na}_{3} \mathrm{VO}_{4}, 1 \mathrm{mM}$ dithiothreitol, and $50 \mu \mathrm{g} / \mathrm{mL}$ phenylmethylsulfonyl fluoride. The concentrations of protein were determined using Bradford assays. In all, $30 \mu \mathrm{g}$ of proteins per sample were fractionated on polyacrylamide gels, and the resulting bands were transferred to nitrocellulose membranes. The membranes were blocked with 5\% skim milk for 1 hour at room temperature and incubated with rabbit polyclonal anti-NMDAR2A (phospho Y1325) antibody (1:1000) or mouse monoclonal anti- $\beta$ actin antibody (1:3000) overnight at $4^{\circ} \mathrm{C}$. After thorough washing, membranes were incubated with horseradish peroxidase-conjugated anti-mouse secondary antibody (1:1000). The signals were visualized using the enhanced chemiluminescence system (Amersham Bioscience, Piscataway, NJ, USA).

\section{Statistical Analysis}

Data in this study are provided as mean value \pm standard error of mean. Statistical analysis of experimental data was performed using one-way analysis of variance, followed by Tukey's post hoc analysis. Statistical significance was assigned as *, \#, $\S$, or $\ddagger$ for $p<0.05$; **, \#\#, $\S$, or $\uparrow+$ for $p<0.01$; and $* * *$, \#\#\#, $\S \S$, or $\neq+\ddagger$ for $p<0.001$.

\section{RESULTS}

Ischemic Edema in Rat Hippocampal Slices Involves Activation of $N$-Methyl-D-Aspartic Acid Receptors

First, we examined whether NMDARs are involved in the OGD-induced edema formation in hippocampal slices (Figure 2A). The average water content of rat hippocampal slices incubated in OGD-ACSF solution was $88.05 \pm 0.46 \%$ compared 

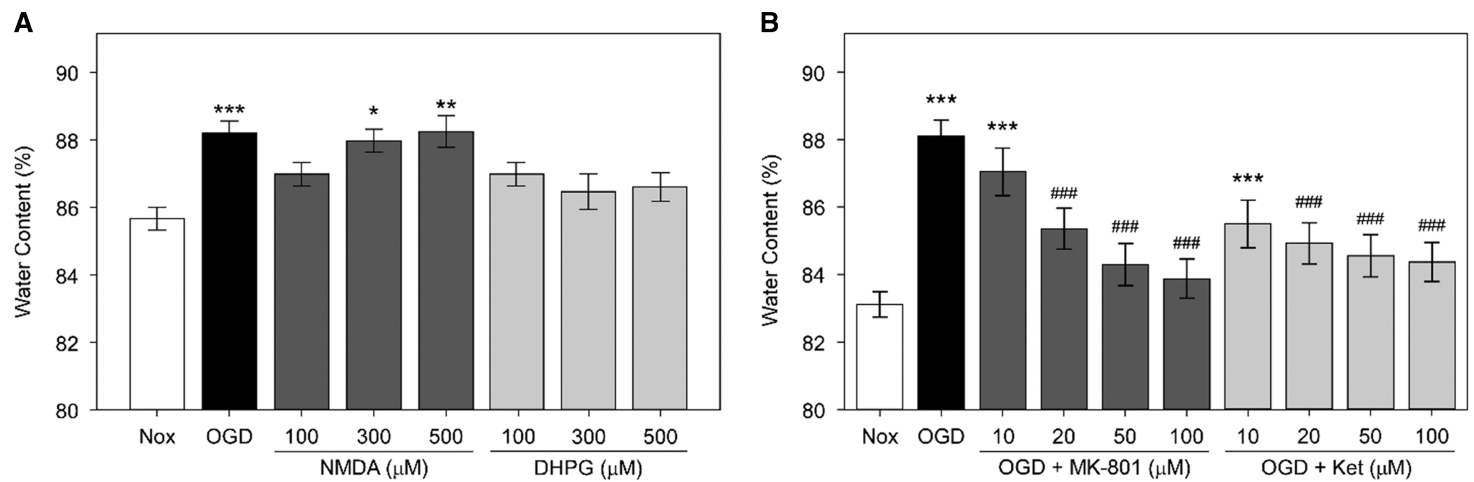

Figure 2: Role of N-methyl-D-aspartic acid receptor (NMDARs) in oxygen and glucose deprivation (OGD)-induced edema in rat hippocampal slices. (A) Average water content of rat hippocampal slices exposed to OGD, NMDA, or (S)3,5-dihydroxyphenylglycine (DHPG). Rat hippocampal slices were incubated in OGD-artificial CSF (ACSF) solution or were treated with NMDA or DHPG at 100,300, or $500 \mu M$ in normoxic ACSF for an hour. Rat hippocampal slices incubated in normoxic ACSF for an hour without any treatment (Nox) are included. Statistical significance levels compared with Nox are indicated by * $(\mathrm{n}=10$, each). (B) Average water content of rat hippocampal slices treated with $O G D$ and NMDAR antagonists. Rat hippocampal slices were incubated for an hour in OGD-ACSF solution in the presence or absence of the NMDAR antagonists MK-801 or ketamine (Ket) at a concentration of 10, 20, 50, or 100 $\mu M$. Rat hippocampal slices incubated in normoxic ACSF solution for an hour without any treatment (Nox) are included as control. Statistical significance for experimental groups is presented as * or \# in comparison to Nox or OGD, respectively $(\mathrm{n}=10$, each $)$.

with $83.06 \pm 0.38 \%$ in the non-treated normoxic group (Nox; $p<0.001)$. We found that two NMDAR antagonists, MK-801 and ketamine ${ }^{17}$ inhibited the OGD-induced edema at $10,20,50$, and $100 \mu \mathrm{M}$ in a concentration-dependent manner $(p<0.001$ for 20 , 50 , and $100 \mu \mathrm{M}$ of each inhibitor). The average water content of rat hippocampal slices incubated under OGD conditions and treated with 50 or $100 \mu \mathrm{M}$ MK-801 were $84.30 \pm 0.44 \%$ and $83.89 \pm 0.41 \%$, respectively, whereas those treated with 50 or $100 \mu \mathrm{M}$ ketamine were $84.61 \pm 0.44 \%$ and $84.37 \pm 0.31 \%$, respectively. These values are significantly lower than those of the OGD group and comparable to the values in the untreated normoxic group.

Next, we examined whether NMDA (an iGluR agonist) and DHPG (a selective mGluR agonist) induce edema by themselves. We observed that only treatment with NMDA, but not with DHPG, led to significant edema in brain slices (Figure 2B). The water content of NMDA-treated slices increased in a concentration-dependent manner. Notably, the average water contents of slices incubated in the presence of 300 or $500 \mu \mathrm{M}$ NMDA were $87.99 \pm 0.24 \%$ and $88.22 \pm 0.4 \%$, respectively. Therefore, these values were comparable to those of the OGD group $(88.23 \pm 0.36 \%)$ and significantly higher than those of the untreated Nox group $(85.55 \pm 0.26 \%)$. However, there was only a slight and statistically insignificant increase in the water content of slices incubated with similar concentrations of DHPG. The average water contents in slices incubated in the presence of 100,300 , and $500 \mu \mathrm{M}$ DHPG were $87.27 \pm 0.44 \%, 86.41 \pm 0.46 \%$, and $86.6 \pm 0.37 \%$, respectively.

\section{Ultrasound Stimulation Reduces $N$-Methyl-D-Aspartic Acid- Induced Edema}

Next, we assessed the effects of direct ultrasound stimulation on NMDA-treated rat hippocampal slices. We found that ultrasound stimulation, particularly at an intensity of $100 \mathrm{~mW} / \mathrm{cm}^{2}$, inhibited edema significantly in slices exposed to either OGD or $500 \mu \mathrm{M}$ NMDA (Figure 3A). Average water contents of LIUS- stimulated versus nonstimulated groups were $85.91 \pm 0.5 \%$ versus $88.51 \pm 0.3 \%$ for OGD $(p<0.001), 85.72 \pm 0.32 \%$ versus $88.95 \pm 0.35 \%$ for NMDA $(p<0.001)$, and $86.22 \pm 0.44 \%$ versus $87.74 \pm 0.54 \%$ for DHPG. All ultrasound-stimulated groups exhibited water contents that were comparable to those of the normoxic group $(86.23 \pm 0.48 \%)$.

Furthermore, we found that the inhibitory effects of ultrasound stimulation against NMDA-induced edema were intensitydependent (Figure 3B), with the ultrasound intensity of $100 \mathrm{~mW} / \mathrm{cm}^{2}$ being the most potent stimulus. The average water content of slices in the NMDA-treated group without ultrasound stimulation was $88.47 \pm 0.23 \%$, whereas the mean values in LIUS-stimulated groups were $87.45 \pm 0.17 \%, 86.42 \pm 0.22 \%$ $(p<0.01)$, and $84.74 \pm 0.39 \%(p<0.001)$ for 30,50 , and $100 \mathrm{~mW} / \mathrm{cm}^{2}$, respectively. Particularly, the water content of the $100 \mathrm{~mW} / \mathrm{cm}^{2}$ ultrasound group was comparable to that of the untreated normoxic group $(84.78 \pm 0.36 \%)$.

\section{Ultrasound Stimulation Decreases Oxygen and Glucose Deprivation- or $N$-Methyl-D-Aspartic Acid-Induced Phosphorylation of $N$-Methyl-D-Aspartic Acid Receptors}

It has been shown previously in in vitro models of ischemia that an increased phosphorylation of NMDARs is involved in OGD-induced edema. ${ }^{18,19}$ In accordance with these studies, we found that both OGD (Figure 4A) and NMDA treatments (Figure 4B) increased the amount of phosphorylated NR2A subunits of the NMDAR in rat hippocampal homogenates. The levels of phosphorylated NR2A subunits in the OGD- or NMDA-treated group were more than threefold $(p<0.001)$ the level in the normoxic group. Interestingly, the OGD- or NMDA-induced tyrosine phosphorylation of NMDAR subunits was decreased by ultrasound stimulation in an intensity-dependent manner. In particular, the 50 and $100 \mathrm{~mW} / \mathrm{cm}^{2}$ ultrasound groups showed nearly a $30 \%$ and 50\% $(p<0.001)$ decrease, respectively, in the levels of phosphorylated NMDAR compared with that in the OGD group 
A

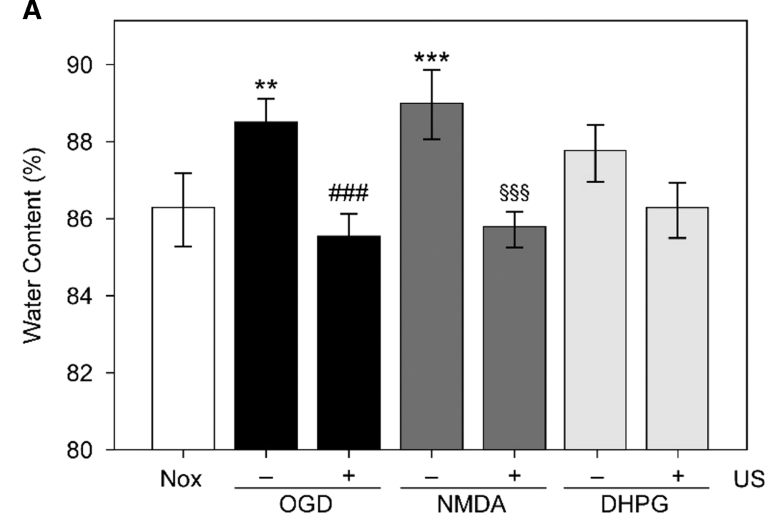

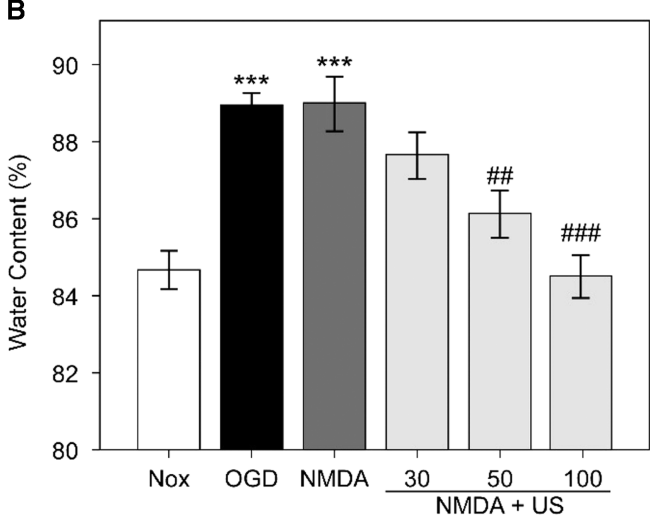

Figure 3: Effects of ultrasound stimulation (US) on N-methyl-D-aspartic acid (NMDA)- or (S)-3,5dihydroxyphenylglycine (DHPG)-induced edema in rat hippocampal slices. (A) Average water content of rat hippocampal slices treated with NMDA or DHPG with or without US. Rat hippocampal slices were incubated for an hour in oxygen and glucose deprivation (OGD)-artificial CSF (ACSF) solution or were treated with $500 \mu M$ NMDA or DHPG in normoxic ACSF with or without US at $100 \mathrm{~mW} / \mathrm{cm}^{2}$ for 20 minutes before incubation. Rat hippocampal slices incubated in normoxic ACSF solution for an hour without any treatment (Nox) are included as the control group. Statistical significance levels between experimental groups are indicated by * compared with Nox, by \# compared with $O G D$, or by $\$$ compared with NMDA $(\mathrm{n}=10$, each). (B) Average water content of rat hippocampal slices stimulated with ultrasound at various acoustic intensities. Rat hippocampal slices were incubated for an hour in OGD-ACSF solution, or treated with $500 \mu M$ NMDA in normoxic ACSF with or without US at 30, 50 , or $100 \mathrm{~mW} / \mathrm{cm}^{2}$ for 20 minutes before incubation. Rat hippocampal slices incubated in normoxic ACSF solution for an hour without any treatment (Nox) are included. Statistical significance levels are shown as * or \# in comparison with Nox or NMDA, respectively $(\mathrm{n}=10$, each).

without ultrasound treatment. Similarly, ultrasound stimulation at 50 and $100 \mathrm{~mW} / \mathrm{cm}^{2}$ decreased the phosphorylated NMDAR by nearly $50 \%(p<0.001)$ after NMDA treatment.

\section{DISCUSSION}

Brain edema, a major causal factor for morbidity and mortality in a wide variety of nervous system disorders, is a pathological condition characterized by a net increase in brain water content, brain tissue volume, and intracranial pressure. This results in brain herniation, irreversible brain damage, and eventually death. ${ }^{20} \mathrm{We}$ have previously demonstrated that LIUS stimulation significantly reduces OGD- and glutamate-induced edema formation in the rat brain by reducing the expression and altering the localization of AQP4 water channels in astrocytic foot processes. ${ }^{6}$ Excessive release of glutamate has been implicated in the pathophysiology
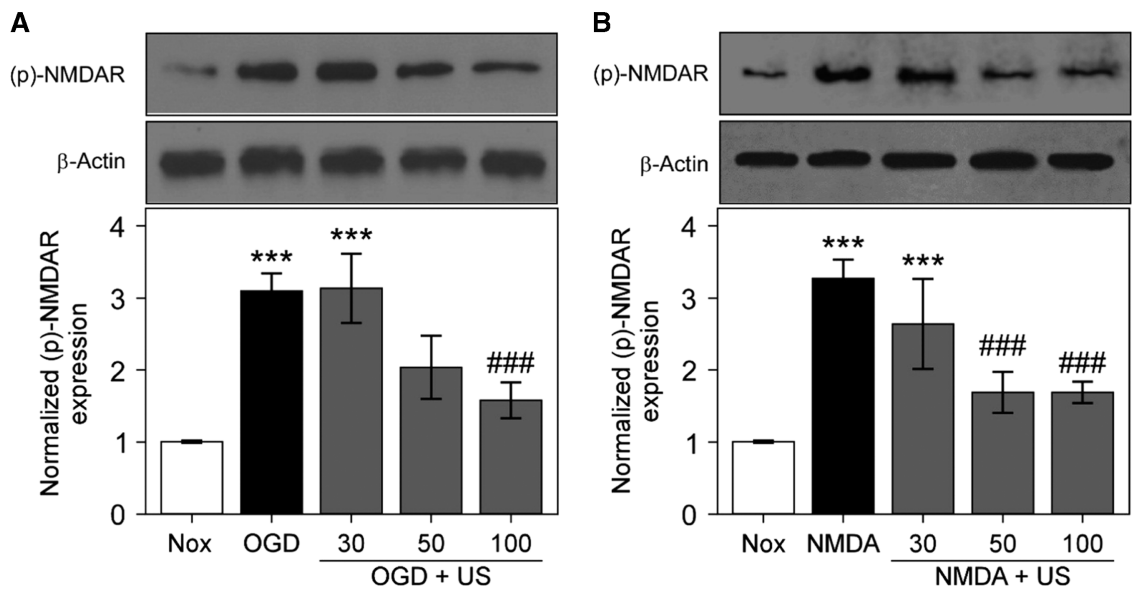

Figure 4: Effect of ultrasound stimulation (US) on tyrosine phosphorylation of the NR2A subunit of N-methyl-D-aspartic acid receptor (NMDARs). Rat hippocampal slices were incubated for an hour in oxygen and glucose deprivation (OGD)-artificial CSF (ACSF) solution (A) or in normoxic ACSF containing $500 \mu M$ NMDA (B) with or without US at 30,50, or $100 \mathrm{~mW} / \mathrm{cm}^{2}$ for 20 minutes before incubation. Rat hippocampal slices incubated in normoxic ACSF solution for an hour without any treatment (Nox) are included. The hippocampal slices were minced and homogenized in RIPA buffer. Total proteins were extracted from the homogenate, and $30 \mu \mathrm{g}$ of each extract was used for Western blotting. $\beta$-Actin was used as a loading control. Statistical significance levels between experimental groups are shown as * or as \# compared with Nox or OGD (A)/NMDA (B), respectively. $\mathrm{n}=3$ for each experiment. 
of cytotoxic brain edema. ${ }^{21}$ A massive release of glutamate activates NMDARs, a member of the iGluR family, which initiates a significant increase in intracellular $\mathrm{Na}^{+}$and $\mathrm{Cl}^{-}$ion concentrations. ${ }^{5}$ Activation of NMDARs has been attributed to tyrosine phosphorylation of its subunits. In particular, transient ischemia increases tyrosine phosphorylation of the NR2A and NR2B subunits of the NMDAR in the rat hippocampus. ${ }^{22,23}$ In this study, we further explore the mechanisms of OGD-induced edema. We show, in addition to previously published results, that OGDinduced edema is mediated by activation of NMDARs and that this mechanism involves increased phosphorylation of the NR2A subunits of NMDARs. We demonstrate that, under normoxic conditions, hippocampal slices incubated with 300 or $500 \mu \mathrm{M}$ NMDA exhibit a significantly higher water content than those without any treatment. However, the mGluR agonist DHPG induces only a slight and statistically nonsignificant increase in the water content. Furthermore, treatment with the NMDAR inhibitors MK-801 or ketamine reduced the OGD-induced edema in a concentration-dependent manner, albeit the inhibitory action of ketamine was less prominent than that of MK-801. It is of relevance here to note that MK-801 exhibits a greater potency on GluN2A and GluN2B subunits of NMDARs, whereas ketamine binds with higher affinity to the GluN2C subunit. ${ }^{24}$ In addition, it has been reported earlier that OGD upregulates NMDAR subunits, which was inhibited by MK-801. ${ }^{25}$ On the basis of these findings, we reasoned that NMDARs, rather than the mGluRs, might play a substantial role in the ischemia-induced cytotoxic edema in hippocampal slices in vitro. This is consistent with previous findings showing that an excessive activation of NMDARs caused by OGD-induced extracellular glutamate release is one of the key factors in cytotoxic edema formation. ${ }^{15}$ In addition, it has been reported that a high expression level of NMDARs is associated with the severity of an ischemic injury, supporting a major role of NMDARs in the development of brain edema. $^{26}$

We have previously reported that ultrasound stimulation for 20 minutes with an acoustic intensity of $100 \mathrm{~mW} / \mathrm{cm}^{2}$ inhibits OGD- and glutamate-induced edema. ${ }^{6}$ As we and others ${ }^{27}$ confirmed that OGD-induced edema involves the activation of NMDARs, we next determined whether ultrasound stimulation inhibits the development of NMDA-induced edema in rat hippocampal slices. Notably, NMDARs are mechanosensitive and exhibit a unique shift in actions following mechanical stimulation. ${ }^{16}$ It has been shown that mechanical stimulation can act as a distinct regulator of NMDAR functions. For instance, rapid neuronal stretching has been shown to induce a loss of the voltagedependent $\mathrm{Mg}^{2+}$ block in NMDARs. ${ }^{28}$ In the light of these reports, we hypothesized that LIUS, a type of mechanical stimulation, might exert effects on the NMDA-induced edema formation. Interestingly, we observed that ultrasound stimulation inhibits NMDA-induced edema in an intensity-dependent manner. The water content of hippocampal slices after ultrasound stimulation with an intensity of $100 \mathrm{~mW} / \mathrm{cm}^{2}$ was significantly lower than that in the NMDA-treated group without ultrasound treatment and was comparable to that of the untreated normoxic group.

Studies on the mechanisms of ischemia-induced edema implicate enhanced tyrosine phosphorylation of NMDAR subunits. ${ }^{18}$ We too observed that both OGD and NMDA treatments increase the levels of tyrosine-phosphorylated NR2A subunits.
Interestingly, we found that LIUS stimulation decreases tyrosine phosphorylation of the NR2A subunit in an intensity-dependent manner in both OGD and NMDA treatments. Thus, our data show that NMDARs are sensitive toward LIUS stimulation and that this stimulation can modulate the phosphorylation state of NMDARs. We think that LIUS stimulation might decrease the tyrosine phosphorylation and inhibit the overactivation of NMDARs, thereby reducing the subsequent ion influx into hippocampal cells. We propose NMDARs as the potential target of the observed ultrasound effects on the basis of previous reports that demonstrate that NMDAR subunits are mechanosensitive 16,29 and that mechanical stress activates NMDARs. ${ }^{30}$ We think that ultrasound waves as a type of mechanical stimulation might decrease tyrosine phosphorylation of NMDARs and thus affect and modulate NMDAR functions. The LIUS-induced decrease of NMDAR functions might result in an inhibition of the ischemiainduced edema. However, it should be mentioned that further experimental evidence is needed to elucidate the mechanism by which ultrasound stimulation decreases tyrosine phosphorylation of NMDARs. Toward downstream pathways, it has been shown previously that NMDARs mediate protein phosphorylation and can stimulate neuronal gene expression via intracellular signaling such as the Ras-mitogen-activated protein kinase (MAPK) or the transcription factor cyclic adenosine monophosphate response element-binding protein pathways. ${ }^{31}$ Similarly, protein phosphorylation can regulate the function of AQP4 water channels. ${ }^{32}$ Hence, it is possible that an LIUS-induced decrease in NMDAR activation might affect subsequent protein phosphorylation and eventually reduce AQP4 activity as well, which further helps to reduce water influx into cells and thereby inhibits the formation of brain edema.

\section{CONCLUSIONS}

In conclusion, we demonstrate that OGD-induced edema in hippocampal slices is mediated by activation of NMDARs and that LIUS stimulation reduces the OGD- or NMDA-induced edema formation. In addition, LIUS stimulation prevents the OGD-induced increase in tyrosine phosphorylation of NR2A subunits of the NMDAR. Considering these data, we conclude that the inhibition of OGD-induced edema formation by LIUS stimulation possibly involves an inactivation of NMDARs and their downstream signaling pathways. $N$-Methyl-D-aspartic acid receptors as mechanosensitive channels could be a potential target of LIUS effects, but further investigations are required to elucidate the exact mechanism of LIUS action.

\section{ACKNOWLEDGMenT}

The study was supported by an Inha University research grant (grant number 55821).

\section{DisClosures}

BH and MBK have the following disclosure: the current study was supported by an Inha University research grant. SRP and $\mathrm{BHC}$ have nothing to disclose.

\section{Statement of Authorship}

This manuscript contains original data. All authors have made substantial contributions to this study. BH contributed to the 
conception and design of the study, performed experiments, analyzed and interpreted data, and drafted the manuscript. MBK performed experiments, interpreted data, and revised the manuscript. SRP and BHC made substantial contributions to the conception of the manuscript, helped to interpret the data, and revised the manuscript. All authors have read and approved the final version of the article.

\section{REFERENCES}

1. Unterberg AW, Stover J, Kress B, Kiening KL. Edema and brain trauma. Neuroscience. 2004;129(4):1019-27.

2. Kahle KT, Simard JM, Staley KJ, Nahed BV, Jones PS, Sun D. Molecular mechanisms of ischemic cerebral edema: role of electroneutral ion transport. Physiology. 2009;24(4):257-65.

3. Su G, Kintner DB, Sun D. Contribution of $\mathrm{Na}(+)-\mathrm{K}(+)-\mathrm{Cl}(-)$ cotransporter to high-[K(+)](o) - induced swelling and EAA release in astrocytes. Am J Physiol Cell Physiol. 2002;282(5): C1136-46.

4. Khanna A, Kahle KT, Walcott BP, Gerzanich V, Simard JM. Disruption of ion homeostasis in the neurogliovascular unit underlies the pathogenesis of ischemic cerebral edema. Transl Stroke Res. 2014;5(1):3-16.

5. Liang D, Bhatta S, Gerzanich V, Simard JM. Cytotoxic edema: mechanisms of pathological cell swelling. Neurosurg Focus. 2007;22(5):E2

6. Karmacharya MB, Kim KH, Kim SY, et al. Low intensity ultrasound inhibits brain oedema formation in rats: potential action on AQP4 membrane localization. Neuropathol Appl Neurobiol. 2015;41(4):e80-94.

7. Karmacharya MB, Hada B, Park SR, Choi BH. Low-intensity ultrasound decreases alpha-synuclein aggregation via attenuation of mitochondrial reactive oxygen species in MPP $(+)$-treated PC12 cells. Mol Neurobiol. 2017;54:6235-44.

8. Kim NK, Kim CY, Choi MJ, Park SR, Choi BH. Effects of lowintensity ultrasound on oxidative damage in retinal pigment epithelial cells in vitro. Ultrasound Med Biol. 2015;41(5):1363-71.

9. Karmacharya MB, Hada B, Park SR, Choi BH. Low-intensity ultrasound reduces high glucose-induced nitric oxide generation in retinal pigment epithelial cells. Ultrasound Med Biol. 2018;44(3):647-56.

10. Chung JI, Barua S, Choi BH, Min BH, Han HC, Baik EJ. Antiinflammatory effect of low intensity ultrasound (LIUS) on complete Freund's adjuvant-induced arthritis synovium. Osteoarthritis Cartilage. 2012;20(4):314-22.

11. Choi BH, Kim KH, Karmacharya MB, Min B-H, Park SR. Lowintensity ultrasound in stem cells and tissue engineering. In: Schatten $\mathrm{H}$, editor. Cell and molecular biology and imaging of stem cells. Hoboken, NJ: John Wiley \& Sons Inc.; 2014, pp. 45-65.

12. Cho S, Wood A, Bowlby MR. Brain slices as models for neurodegenerative disease and screening platforms to identify novel therapeutics. Curr Neuropharmacol. 2007;5(1):19-33.

13. Holopainen IE. Organotypic hippocampal slice cultures: a model system to study basic cellular and molecular mechanisms of neuronal cell death, neuroprotection, and synaptic plasticity. Neurochem Res. 2005;30(12):1521-28

14. Dong WQ, Schurr A, Reid KH, Shields CB, West CA. The rat hippocampal slice preparation as an in vitro model of ischemia. Stroke. 1988;19(4):498-502.
15. Xiao F. Bench to bedside: brain edema and cerebral resuscitation: the present and future. Acad Emerg Med. 2002;9(9): 933-46.

16. Singh $\mathrm{P}$, Doshi $\mathrm{S}$, Spaethling JM, et al. $N$-Methyl-D-aspartate receptor mechanosensitivity is governed by $\mathrm{C}$ terminus of NR2B subunit. J Biol Chem. 2012;287(6):4348-59.

17. de Bartolomeis A, Sarappa C, Buonaguro EF, et al. Different effects of the NMDA receptor antagonists ketamine, MK-801, and memantine on postsynaptic density transcripts and their topography: role of Homer signaling, and implications for novel antipsychotic and pro-cognitive targets in psychosis. Prog Neuropsychopharmacol Biol Psychiatry. 2013;46:1-12.

18. Pavlov D, Mielke JG. Tyrosine phosphorylation of the NMDA receptor following cerebral ischaemia. In Huang $\mathrm{C}$ editor Protein phosphorylation in human health. Rijeka: InTech; 2012, p. Ch. 09.

19. Takagi N. Protein tyrosine phosphorylation in the ischemic brain. J Pharmacol Sci. 2014;125(4):333-9.

20. Papadopoulos MC, Saadoun S, Binder DK, Manley GT, Krishna S, Verkman AS. Molecular mechanisms of brain tumor edema. Neuroscience. 2004;129(4):1011-20.

21. Stokum JA, Gerzanich V, Simard JM. Molecular pathophysiology of cerebral edema. J Cereb Blood Flow Metab. 2016;36(3):513-38.

22. Takagi N, Sasakawa K, Besshoh S, Miyake-Takagi K, Takeo S. Transient ischemia enhances tyrosine phosphorylation and binding of the NMDA receptor to the Src homology 2 domain of phosphatidylinositol 3-kinase in the rat hippocampus. J Neurochem. 2003;84(1):67-76.

23. Takagi N, Shinno K, Teves L, Bissoon N, Wallace MC, Gurd JW. Transient ischemia differentially increases tyrosine phosphorylation of NMDA receptor subunits $2 \mathrm{~A}$ and $2 \mathrm{~B}$. J Neurochem. 1997;69(3):1060-5.

24. Sleigh J, Harvey M, Voss L, Denny B. Ketamine - more mechanisms of action than just NMDA blockade. Trends Anaesth Crit Care. 2014;4(2):76-81.

25. Neuhaus W, Burek M, Djuzenova CS, et al. Addition of NMDAreceptor antagonist MK801 during oxygen/glucose deprivation moderately attenuates the upregulation of glucose uptake after subsequent reoxygenation in brain endothelial cells. Neurosci Lett. 2012;506(1):44-9.

26. Choi DW, Rothman SM. The role of glutamate neurotoxicity in hypoxic-ischemic neuronal death. Annu Rev Neurosci. 1990; $13: 171-82$.

27. Rungta Ravi L, Choi Hyun B, Tyson John R, et al. The cellular mechanisms of neuronal swelling underlying cytotoxic edema. Cell. 2015;161(3):610-21.

28. Zhang L, Rzigalinski BA, Ellis EF, Satin LS. Reduction of voltagedependent $\mathrm{Mg}^{2+}$ blockade of NMDA current in mechanically injured neurons. Science. 1996;274(5294):1921-23.

29. Ma MC, Huang HS, Chen YS, Lee SH. Mechanosensitive $N$-methylD-aspartate receptors contribute to sensory activation in the rat renal pelvis. Hypertension. 2008;52(5):938-44.

30. Maneshi MM, Maki B, Gnanasambandam R, et al. Mechanical stress activates NMDA receptors in the absence of agonists. Sci Rep. 2017;7:39610.

31. Sala C, Rudolph-Correia S, Sheng M. Developmentally regulated NMDA receptor-dependent dephosphorylation of cAMP response element-binding protein (CREB) in hippocampal neurons. J Neurosci. 2000;20(10):3529-6.

32. Han Z, Wax MB, Patil RV. Regulation of aquaporin-4 water channels by phorbol ester-dependent protein phosphorylation. J Biol Chem. 1998;273(11):6001-4. 